\title{
Kepastian Hukum Dalam Penyelenggaraan Layanan Dompet Elektronik Dalam Sistem Pembayaran Dikaitkan Dengan Prinsip Lancar, Aman, Efisien, Dan Andal Berdasarkan PBI Nomor 20/6/PBI/2018 Tentang Uang Elektronik
}

\author{
Elsa Debora Manurung \\ Universitas Padjadjaran \\ elsa16004@mail.unpad.ac.id \\ Lastuti Abubakar \\ Universitas Padjadjaran \\ lastuti.abubakar@unpad.ac.id \\ Tri Handayani \\ Universitas Padjadjaran \\ tri.handayani@unpad.ac.id
}

DOI: 10.23917/jjr.v10i1.10226

\begin{abstract}
Submission
Track:

ABSTRAK

Received:

Tujuan : Penelitian ini bertujuan untuk mengetahui penerapan prinsip

10 Februari 2020 efisien, lancar, aman, dan andal serta mengetahui penerapan aspek kepastian hukum dalam penyelenggaraan dompet elektronik ditinjau dari PBI tentang Uang Elektronik, PBI tentang Penyelenggaraan Pemrosesan Transaksi Pembayaran dan PBI tentang Penyelengaraan Teknologi Finansial.
\end{abstract}

Final Revision:

3 Juni 2020

Metodologi : Metode yang digunakan dalam penelitian adalah pendekatan yuridis normatif dan spesifikasi penelitian deskriptif analitis yang mengkaji dan meneliti data sekunder berupa bahan

Available online: hukum primer berdasarkan PBI tentang Uang Elektronik.

31 Juli 2020

Temuan : Adanya PBI tentang Uang Elektronik, PBI tentang Penyelenggaraan Pemrosesan Transaksi Pembayaran dan PBI tentang Penyelenggaraan Teknologi Finansial guna menciptakan kelancaran

Corresponding pada sistem pembayaran. Implementasi penyelenggaraan sistem

Author: pembayaran dompet elektronik telah memenuhi prinsip lancar, aman, Elsa Debora efisien, dan andal sesuai dengan amanat dalam PBI tentang Uang Elektronik, PBI tentang Penyelenggaraan Pemrosesan Transaksi 


\begin{abstract}
Manurung Pembayaran dan PBI tentang Penyelengaraan Teknologi Finansial.
Elsa16004@mail. Penerapan aspek kepastian hukum pada penyelenggaraan dompet unpad.ac.id elektronik sudah terpenuhi dengan penyelesaian permasalahan praktik penyelenggaraan dompet elektronik yang belum memiliki izin untuk memberikan perlindungan hukum bagi konsumen dengan merujuk pada PBI tentang Uang Elektronik yaitu kewajiban kerja sama dengan penyelenggaraan dompet elektronik yang memiliki izin uang elektronik dan memindahkan saldo pengguna dompet elektronik ke dompet elektronik yang telah memiliki izin uang elektronik dari Bank Indonesia.
\end{abstract}

Kegunaan : Penelitian ini bermanfaat baik bagi regulator maupun konsumen dalam penyelenggaraan dompet elektronik dengan menerapkan prinsip lancar, aman, efisien, dan andal serta menerapkan aspek kepastian hukum.

Kebaruan/Orisinalitas : Penerapan prinsip lancar, aman, efisien, dan andal serta aspek kepastian hukum akan tetap dapat terpenuhi dalam mengatasi permasalahan praktik penyelenggaraan dompet elektronik yang belum memiliki izin yaitu izin penyelenggaraan dompet elektronik. Hal tersebut dilakukan dengan melakukan kerja sama dan pemindahan saldo pengguna dompet elektronik terhadap dompet elektronik yang telah memiliki izin dari Bank Indonesia.

〈eywords: Teknologi Finansial, Dompet Elektronik, Uang Elektronik

\title{
PENDAHULUAN
}

Peranan internet dalam teknologi informasi kini digunakan untuk mengembangkan industri keuangan yang dikenal dengan teknologi finansial. Teknologi finansial merupakan produk dan layanan jasa keuangan melalui kombinasi platform teknologi dan model bisnis yang inovatif. (Buckley \& Webster, 2016) Perkembangan teknologi finansial juga membuka peluang untuk pendirian berbagai platform yang memudahkan orang untuk melakukan kegiatan keuangan. Sehingga pada era yang berada pada digitalisasi ini perekonomian mulai terintegrasi melalui sistem online. Hal tersebut memudahkan masyarakat untuk melakukan kegiatan ekonomi. Jika perkembangan teknologi tersebut dikelola dengan baik maka Indonesia memiliki dampak yang signifikan pada stabilitas sistem keuangan. (Lastuti Abubakar \& Tri Handayani, 2018)

Penyelenggaraan teknologi finansial dikategorikan ke dalam beberapa kategori yang salah satunya adalah sistem pembayaran. Perkembangan dengan basis elektronik telah memberikan dampak munculnya inovasi baru yaitu infrastruktur teknologi dalam sistem pembayaran yang diharapkan memberikan kemudahan, fleksibilitas, efisiensi, dan kesederhanaan dalam melakukan transaksi. Bank Indonesia mengadaptasi suatu alat 
pembayaran yang dapat mengakomodasi aspek diatas, yang dikenal dengan uang elektronik. (Mintarsih, 2013) Instrumen uang elektronik kini dapat disimpan dalam dompet elektronik.

Aplikasi dompet elektronik cukup diunduh pada smartphone kemudian pengguna dapat melakukan pembayaran. (Dewan \& Chen, 2014) Aplikasi tersebut berbentuk dompet yang dapat digunakan untuk pembayaran non tunai. Contoh produk dompet elektronik yang ditawarkan perusahaan telekomunikasi diantaranya layanan-layanan dompet elektronik seperti Go-Pay, OVO, DANA, Link Aja, BukaDompet. Hanya dengan saldo yang ada di dalam akun dompet elektronik, setiap transaksi dapat dilaksanakan secara online. Dengan hadirnya dompet elektronik diharapkan dapat mencapai transaksi pembayaran dengan mudah dan cepat tanpa perlu membawa uang tunai. (Bank Indonesia, 2019)

Berdasarkan ketentuan pada PBI Nomor 18/40/PBI/2016 tentang Penyelenggaraan Pemrosesan Transaksi Pembayaran (selanjutnya disebut dengan PBI Penyelenggaraan Pemrosesan Transaksi Pembayaran) bahwa penyelenggara dompet elektronik yang dilakukan oleh lembaga selain bank harus telah memperoleh izin sebagai penerbit uang elektronik. Bank Indonesia mengatur ketentuan uang elektronik dalam PBI Nomor 20/6/PBI/2018 tentang Uang Elektronik (selanjutnya disebut dengan PBI tentang Uang Elektronik) yang dikeluarkan pada tahun 2018. Dalam aturan tersebut dinyatakan bahwa penyelenggara uang elektronik yang menghimpun dana beredar (floating fund) lebih dari Rp 1 miliar harus memiliki izin ke Bank Indonesia dan memiliki lisensi khusus.

Tahun 2017 pada saat aturan tersebut dikeluarkan, maka tidak seluruh dompet elektronik yang sedang beroperasional di Indonesia memiliki izin uang elektronik. Dikarenakan dompet elektronik tersebut telah beroperasional terlebih dahulu sebelum aturan PBI tentang Uang Elektronik diberlakukan. Terdapat dompet elektronik yang layanan operasionalnya dibekukan akibat belum memiliki izin uang elektronik yang ketentuanya secara tegas diatur dalam PBI tentang Uang Elektronik yang kemudian dilakukan perubahan pada tahun 2018. BukaDompet milik Bukalapak dan TokoCash milik Tokopedia termasuk dompet elektronik yang dibekukan operasionalnya oleh Bank Indonesia. Akibat dari dibekukannya layanan dompet elektronik tersebut, fitur penambahan saldo (top up) tidak dapat dilakukan. (Kompas, 2018)

Dari kasus tersebut dompet elektronik yang dibekukan harus memenuhi mekanisme penyelenggaraan dompet elektronik seperti tahap pendaftaran, regulatory sandbox, perizinan dan persetujuan, pemantauan dan pengawasan yang seharusnya menghasilkan sistem pembayaran yang lancar, aman, efisien, dan andal. Oleh karena itu, Penulis akan meneliti implementasi prinsip lancar, aman, efisien, dan andal pada kasus dalam penyelenggaraaan pemrosesan transaksi pembayaran ditinjau dari PBI tentang Uang Elektronik. Pembekuan operasional dompet elektronik tersebut juga harus menerapkan asas kepastian hukum sehingga pengguna dapat memperoleh saldo sesuai dengan saldo yang dimilikinya pada dompet elektronik dibekukan operasionalnya. Penelitian ini juga akan diteliti implementasi 
kepastian hukum dalam penyelenggaraan dompet elektronik yang dibekukan operasionalnya oleh Bank Indonesia.

\section{METODOLOGI PENELITIAN}

Metode yang digunakan dalam penelitian ini adalah deskriptif analistis yang menganalisa obyek penelitian dengan memaparkan situasi dan masalah untuk memperoleh gambaran mengenai situasi dan keadaan, dengan cara pemaparan data yang diperoleh sebagaimana adanya kemudian dianalisis sehingga menghasilkan kesimpulan. (Soerjono Soekanto, 2008) Metode pendekatan yang digunakan adalah yuridis normatif yaitu metode pendekatan dengan menganalisi aturan hukum berupa bahan hukum primer berdasarkan PBI Nomor 20/6/PBI/2018 tentang Uang Elektronik.

\section{PEMBAHASAN}

Praktik yang terjadi terdapat permasalahan pada perizinan dompet elektronik sehingga Bank Indonesia pada tanggal 13 September 2017 mencabut operasional layanan dompet elektronik TokoCash milik Tokopedia dan juga BukaDompet milik Bukalapak. Hal ini dikarenakan perusahaan TokoCash dan BukaDompet belum mendapatkan izin atau lisensi layanan uang elektronik dari Bank Indonesia. Bank Indonesia mengambil tindakan tersebut karena TokoCash menghimpun dana float lebih dari Rp. 1 miliar. Dompet elektronik lain seperti ShopeePay milik Shopee, dan Paytren juga dibekukan oleh Bank Indonesia. (Kompas, 2017)

Berdasarkan perizinan penyelenggara dan pendukung jasa sistem pembayaran yang diberikan Bank Indonesia per 24 Oktober 2019. Shopeepay dan Paytren memiliki izin sebagai penerbit uang elektronik dengan tahun efektif operasional yaitu tahun 2018. Namun TokoCash dan BukuDompet tidak terdapat dalam daftar penyelenggara uang elektronik yang telah memperoleh izin dari Bank Indonesia. (Bank Indonesia, 2019) Hingga saat ini Bank Indonesia belum memberikan izin operasional pada dompet elektronik tersebut. Pembekuan operasional layanan dompet elektronik tersebut diakibatkan terdapat beberapa dompet elektronik yang belum memiliki izin uang elektronik. Namun, TokoCash dan BukaDompet telah beroperasional pada saat sebelum berlakunya PBI tentang uang elektronik tahun 2018.

Jika dilihat Peraturan Bank Indonesia bahwa sebelum dompet elektronik beroperasional maka dilakukan regulatory sandbox guna dilakukan penilaian oleh Bank 
Indonesia apakah penyelenggara sistem pembayaran tersebut termasuk dompet elekronik atau uang elektronik. Berdasarkan pengertian dompet elektronik bahwa dompet elektronik dapat menyimpan uang elektronik. Oleh karena itu, diperlukan izin dari Bank Indonesia sebagai penerbit uang elektronik. Saat izin diperoleh, maka dompet elektronik tersebut dapat melakukan kegiatan operasional. Pada permasalahan dompet elektronik seperti TokoCash dan BukaDompet, kegiatan operasional dibekukan dikarenakan belum dilengkapinya dokumen persyaratan sehingga belum mendapat izin. Jika telah beroperasional maka telah terdapat konsumen yang memakai aplikasi dompet elektronik tersebut. Namun, dompet elektronik yang dibekukan opersionalnya telah melakukan permohonan yang hingga hari ini belum mendapatkan izin dari Bank Indonesia. Berdasarkan hasil penelitian yaitu belum ada tanggal operasional efektif TokoCash dan BukaDompet sehingga hal ini menjadi salah satu bentuk kepastian hukum yang harus diteliti.

\section{Implementasi Prinsip Lancar, Aman, Efisien, dan Andal Terhadap Penyelenggaraan Dompet Elektronik Ditinjau Dari PBI Nomor 20/6/PBI/2018 Tentang Uang Elektronik}

Berkaitan dengan pencapaian visi sistem pembayaran dan mewujudkan tujuan dari penyelenggaraan pemrosesan transaksi pembayaran, maka dompet elektronik diatur dalam sebuah mekanisme penyelenggaraan sistem pembayaran. Bank Indonesia sebagai lembaga pengawas kegiatan sistem pembayaran di Indonesia wajib melakukan pengawasan terhadap setiap transaksi pembayaran melalui kebijakan-kebijakan yang dikeluarkan dengan tujuan mewujudkan keamanan dan efisiensi dalam sistem pembayaran. Hal ini dapat dilakukan melalui monitoring terhadap sistem yang ada dan dalam tahap perencanaan, melakukan penilaian (assessment) terhadap setiap penyelenggara yang akan melakukan kegiatan sistem pembayaran berdasarkan kesesuaian dengan tujuan keamanan dan efisiensi dari setiap kegiatan sistem pembayaran. Bank Indonesia bertanggung jawab dan memiliki wewenang untuk mewujudkan sistem pembayaran yang lancar, aman, efisien, dan andal didasarkan kepada amanat Undang-Undang Bank Indonesia. Dengan demikian sistem pembayaran yang lancar, aman, efisien, dan andal erat kaitannya dengan pengawasan yang dilakukan oleh Bank Indonesia.

Model bisnis baru banyak bermunculan dengan adanya platform digital tersebut. Salah satu produk digital pada sistem pembayaran yang dibahas pada penelitian ini adalah dompet 
elektronik. Tujuan dari dompet elektronik yaitu melahirkan inovasi yang berkaitan dengan teknologi finansial untuk memenuhi kebutuhan masyarakat. Selain itu, inovasi dalam penyelenggaraan pemrosesan transaksi pembayaran wajib memenuhi prinsip-prinsip penting bagi keberlangsungan suatu kegiatan sistem pembayaran sebagaimana dikemukakan sebelumnya yaitu prinsip lancar, aman, efisien, dan andal, sehingga diperlukan pengaturan yang mengedepankan pemenuhan prinsip kehati-hatian dan menajemen risiko yang memadai, serta dengan tetap memperhatikan perlindungan konsumen.

Terdapat mekanisme penyelenggaraan dompet elektronik diatur dalam Pasal 4 PBI Nomor 19/12/PBI/2017 tentang Penyelenggaraan Teknologi Finansial yang meliputi beberapa tahapan, yaitu:

1) Pendaftaran

2) Regulatory Sandbox

3) Perizinan dan persetujuan

4) Pemantauan dan pengawasan

Keempat tahapan ini merupakan tahapan yang wajib dipenuhi oleh setiap pelaku industri teknologi finanasial yang fokus bisnisnya adalah sistem pembayaran. Namun demikian, apabila ditelaah lebih jauh lagi mengenai regulasi Bank Indonesia terkait teknologi finansial seperti PBI Penyelenggaraan Pemrosesan Transaksi Pembayaran, PBI tentang Uang Elektronik. Keempat tahapan ini wajib pula diikuti oleh beberapa pelaku industri teknologi finansial seperti pendukung pasar pun wajib melalui keempat tahapan ini.

Dalam praktiknya, sudah diterapkan yaitu seperti kasus pembekuan layanan dompet elektronik oleh Bank Indonesia tahun 2017 yang terjadi pada dompet elektronik TokoCash milik Tokopedia, BukaDompet milik BukaLapak. Dompet elektronik tersebut tidak terdapat dalam daftar penyelenggara uang elektronik yang telah memperoleh izin dari Bank Indonesia per 24 Oktober 2019. (Bank Indonesia, 2019) Hal ini terjadi karena TokoCash dan BukaDompet telah beroperasional dalam penyelenggaraan layanan dompet elektronik tanpa memiliki izin uang elektronik dari Bank Indonesia, sehingga ketika PBI tersebut dilakukan perubahan, maka Bank Indonesia mengambil tindakan untuk membekukan kedua operasional penyelenggara dompet elektronik tersebut. Hal ini dilakukan karena dalam amanat PBI Nomor 20/6/PBI/2018 tentang Uang Elektronik menjelaskan bahwa jika dana float telah 
diatas Rp1.000.000.000 (satu milyar rupiah) maka penyelenggara jasa sistem pembayaran wajib mengantongi izin uang elektronik dari Bank Indonesia dimana perizinan tersebut juga diatur dalam Pasal 4 PBI tentang Penyelenggaraan Teknologi Finansial.

Analisis tahapan yang diatur dalam Pasal 4 PBI Nomor 19/12/PBI/2017 tentang Penyelenggaraan Teknologi Finansial terhadap kasus BukaDompet dan TokoCash telah diimplementasikan oleh penyelenggara dompet elektronik yaitu Bank Indonesia dan dompet elektronik (BukaDompet dan TokoCash) guna mewujudkan sistem pembayaran melalui dompet elektronik yang sesuai dengan prinsip lancar, aman, efisien, dan andal. Tahap pertama yaitu pendaftaran yang diatur dalam Pasal 5 PBI Nomor 19/12/PBI/2017 tentang Penyelenggaraan Teknologi Finansial menyatakan bahwa:

“penyelenggara teknologi finansial yang akan atau telah melakukan kegiatan yang memenuhi kriteria teknologi finansial atau penyelenggara teknologi finansial dibawah kewenangan otoritas lain yang menyelenggarakan teknologi finansial sistem pembayaran wajib melakukan pendaftaran pada Bank Indonesia.”

BukaDompet dan TokoCash telah beroperasi 7 bulan sebelum dibekukan oleh Bank Indonesia. Analisa dari kasus tersebut bahwa dompet elektronik tersebut telah melakukan pendaftaran sebagai penyelenggara teknologi finansial ke Bank Indonesia. Proses pendaftaran ini sangat penting menurut perspektif hukum, karena melalui proses pendaftaran ini maka dompet elektronik tersebut dapat menerapkan prinsip perlindungan konsumen sesuai dengan produk, layanan, teknologi, dan/atau modes bisnis yang dijalankan. Selain itu juga, menerapkan prinsip manajemen risiko dan kehati-hatian.

Tahapan selanjutnya yaitu regulatory sandbox, pada tahapan ini, penyelenggara sistem pembayaran wajib masuk ke dalam laboratorium uji coba bagi teknologi finansial sebelum produknya dipasarkan ke masyarakat. Kemudian dilakukan observasi pada regulatory sandbox, dan hasilnya terdapat 3 (tiga) status untuk penyelenggara sistem pembayaran yang akan beroperasi di pasar teknologi finansial. Tahun 2018 Otoritas Jasa Keuangan juga mengeluarkan aturan mengenai regulatory sandbox yang tertuang di dalam POJK No.13/POJK.02/2018 tentang Inovasi Keuangan Digital di Sektor Jasa Keuangan. Perbedaaan dari substansi dari regulatory sandbox yang diatur oleh Bank Indonesia dan Otoritas Jasa Keuangan adalah pada kewenangan dalam melakukan uji coba terhadap pelaku teknologi finansial yang akan beroperasi. Bank Indonesia melakukan uji coba pada lingkup sistem 
pembayaran. (PBI tentang Penyelenggaraan Teknologi Finansial) Sedangkan, Otoritas Jasa Keuangan melakukan uji coba pada lingkup layanan jasa keuangan seperti crowdfunding dan peer to peer lending yang berbasis pada teknologi finansial. (POJK Nomor 13/POJK/01/2018 Tentang Inovasi Keuangan Digital di Sektor Jasa Keuangan)

Masa uji coba dalam regulatory sandbox yang dilakukan oleh Bank Indonesia adalah selama 6 (enam) bulan dan dapat diperpanjang satu kali paling lama 6 (enam) bulan. Pihak penyelenggara sistem pembayaran diharuskan untuk melakukan presentasi kepada Bank Indonesia mengenai model bisnis dan manajemen risiko beserta dokumen lengkap. Pada saat berlangsungnya uji coba dalam regulatory sandbox, penyelenggara sistem pembayaran wajib memastikan prinsip perlindungan konsumen serta manajemen risiko dan kehati-hatian diterapkan termasuk dalam melindungi data, informasi, serta dokumen. Juga diperhatikan keamanan dan keandalan sistem yang digunakan untuk menjalankan produk, layanan, teknologi dan/atau model bisnis yang diuji coba dalam regulatory sandbox. (PADG Nomor 19/14/PADG/2017)

Keberadaan regulatory sandbox tersebut diharapkan mampu mendorong keuangan digital yang apabila tidak tepat sasaran maka hanya akan dianggap memainkan peran marginal dan gagal membentuk inovasi. Regulatory sandbox tersebut merupakan langkah mengklasifikasikan suatu penyelenggara sistem pembayaran apakah termasuk dompet elektronik atau uang elektronik. Pengklasifikasian tersebut juga penting untuk menentukan jenis perizinan yang akan diajukan seperti permohonan izin penyelenggara sistem pembayaran, pendukung pasar, izin penyelenggara transfer dana atau penyelenggara penunjang. Regulatory Sandbox merupakan suatu ruang uji coba yang aman untuk menguji penyelenggara teknologi finansial berserta produk, layanan, teknologi dan/atau model bisnis lainnya telah memenuhi kriteria teknologi finansial. Setelah mendapatkan status dari Bank Indonesia maka penyelenggara sistem pembayaran tersebut dapat melakukan permohonan izin uang elektronik atau dompet elektronik. (Lastuti Abubakar \& Tri Handayani, 2018)

Kasus dompet elektronik tersebut terjadi pada saat bulan ketujuh setelah produk dipasarkan kemudian operasional dompet elektronik tersebut dibekukan oleh Bank Indonesia sehingga fitur penambahan saldo tidak dapat berfungsi. Hal ini dilakukan oleh Bank Indonesia dikarenakan terdapat persyaratan yang belum dilengkapi perusahaan dompet elektronik tersebut. (Tribun, 2017) Namun demikian, transaksi yang diberhentikan adalah kegiatan 
operasional pada transaksi melalui fitur penambahan saldo (top up) saja. Dompet elektronik yang dibekukan fitur top up kemudian melakukan perpindahan akun pengguna layanan dompet elektronik kepada pihak penyelenggara jasa sistem pembayaran lain yaitu OVO yang telah bekerjasama dengan Tokopedia dan Bukalapak melakukan migrasi kepada DANA yang merupakan pihak yang telah mendapatkan izin penerbit uang elektronik Bank Indonesia untuk melakukan kegiatan di sektor sistem pembayaran.

Dikarenakan pada saat regulatory sandbox selain harus terdaftar di Bank Indonesia, teknologi finansial tersebut dikategorikan ke dalam sistem pembayaran. Selain itu, mengandung unsur inovasi, dapat digunakan masyarakat luas, telah dilengkapi dengan identifikasi dan mitigasi risiko serta hal lain yang dianggap penting oleh Bank Indonesia. Perusahaan yang masuk ke dalam regulatory sandbox, memiliki kewajiban untuk memastikan dilakukannya prinsip perlindungan konsumen, manajemen risiko dan kehati-hatian yang memadai. Perusahaan wajib menyampaikan laporan pelaksanaan uji coba, baik secara reguler maupun insidental sesuai dengan permintaan Bank Indonesia serta menaati ketentuan peraturan perundang-undangan. Selama pelaksanaan uji coba dalam regulatory sandbox, Bank Indonesia melakukan pendampingan dan review sebagai dasar untuk menetapkan status hasil uji coba penyelenggara teknologi finansial. (PBI tentang Penyelenggaraan Teknologi Finansial).

Pada Bab IV Teknologi Finansial dan Peraturan Dewan Gubernur tentang Regulatory Sandbox menjelaskan terdapat prinsip regulatory sandbox yaitu:

a) Criteria-based process

Prinsip ini untuk menetapkan peserta regulatory sandbox memperhatikan pemenuhan kriteria yang ditetapkan Bank Indonesia.

b) Transparansi

c) Proporsionalitas

Mempertimbangkan jenis, skala, dan risiko dari produk layanan, teknologi, dan/atau model bisnis yang diuji coba.

d) Keadilan

Penyelenggara teknologi finansial memiliki kesempatan yang sama sepanjang memenuhi kriteria Bank Indonesia. 
e) Kesetaraan

Ketentuan mengenai regulatory sandbox berlaku bagi seluruh penyelenggara teknologi finansial

f) Forward looking

Mempertimbangan potensi ke depan serta manfaat kepada masyarakat dan perekenomian.

Dalam mekanisme regulatory sandbox, pada dasarnya penting bagi Bank Indonesia untuk mendapatkan keyakinan dari pelaku Teknologi Finansial seperti dompet elektronik TokoCash dan BukaDompet atas pengadaan sistem informasi yang menjadi suatu kewajiban sebagaimana diatur dalam Pasal 20 Ayat (2) PBI Nomor 18/40/PBI/2016 tentang Penyelenggaraan Pemrosesan Transaksi Pembayaran memuat ketentuan penerapan standar keamanan sistem informasi, sehingga tujuan dari penyelenggaraan sistem pembayaran di Indonesia yang mencirikan pada prinsip efisien, lancar, aman dan andal dapat terlaksana dengan baik. Oleh karena itu, sertifikasi keandalan khusus untuk informasi teknologi bagi pelaku dompet elektronik menjadi sesuatu yang penting untuk didapatkan. Selain itu, penerapan standar keamanan sistem informasi oleh dompet elektronik harus memenuhi sertifikasi dan/ atau standar keamanan dan keandalan sistem yang berlaku umum yang ditetapkan oleh Bank Indonesia atau otoritas/lembaga terkait.

Pemenuhan sertifikasi keamanan dan keandalan sistem yang ditetapkan oleh Bank Indonesia pada Pasal 20 PBI 18/40/PBI/2016 tidak memberikan penjelasan secara konkrit mengenai lembaga yang memberikan sertifikasi tersebut. Namun, pada unsur mengingat yang merupakan landasan yang bersifat yuridis bagi pembentukan (Maria Farida, 2007) PBI 18/40/PBI/2016 tentang Penyelenggaraan Pemrosesan Transaksi Pembayaran tersebut salah satunya adalah Undang-Undang Nomor 19 Tahun 2016 tentang Perubahan Atas UndangUndang Nomor 11 Tahun 2008 tentang Informasi dan Transaksi Elektronik (selanjutnya disebut dengan “UU ITE”). Peraturan pelaksana dari UU ITE yaitu PP PSTE yang mengatur mengenai penyelenggara sertifikasi elektronik dan sertifikasi keandalan.

Sertifikasi keandalan dan elektronik tersebut sangat penting untuk dimiliki penyelenggara transaksi pembayaran yaitu melindungi konsumen dalam transaksi elektronik dan juga menjadi jaminan bahwa pelaku usaha telah memenuhi kriteria yang ditentukan oleh lembaga sertifikasi keandalan. Pasal 42 PP PSTE menjelaskan bahwa penyelenggaraan 
transaksi elektronik wajib menggunakan sertifikat elektronik yang diterbitkan oleh Penyelenggara Transaksi Elektronik Indonesia. Pada saat penyelenggaraan transaksi elektronik dapat menggunakan sertifikat keandalan yang diterbitkan oleh Lembaga Sertifikasi Keandalan yang terdaftar. Sertifikat keandalan pada Pasal 1 angka (27) PP PSTE adalah dokumen yang menyatakan pelaku usaha yang menyelenggarakan transaksi elektronik telah lulus audit atau uji kesesuaian dari Lembaga Sertifikasi Keandalan.

Proses berlangsungnya penyelenggaraan transaksi elektronik oleh Penyelenggara Sistem Elektronik Lingkup Publik harus memperhatikan aspek keamanan, keandalan, dan efisiensi. Proses sertifikasi keandalan mencakup pemeriksaan terhadap informasi yang lengkap dan benar dari pelaku usaha seperti identitas pelaku usaha, kebijakan dan prosedur perlindungan privasi, pengamanan sistem dan penyataan jaminan atas barang dan/atau jasa yang ditawarkan. Lembaga sertifikasi keandalan menerbitkan sertifikat keandalan dengan beberapa kategori yaitu registrasi identitas, keamanan sistem elektronik, kebijakan privasi. (Pasal 75 dan 76 PP tentang Penyelenggaraan Sistem dan Transaksi Elektronik). Dengan demikian, objek dari sertifikasi keandalan ada pada kemampuan pelaku usaha yang menyelenggarakan transaksi elektronik bukan pada dokumen elektronik maupun transaksi elektronik. Hal ini juga ditujukan melindungi konsumen dalan transaksi elektronik dan menunjukkan bahwa pelaku usaha telah memenuhi kriteria yang ditentukan oleh lembaga sertifikasi keandalan.

Analisis kasus bahwa regulatory sandbox telah diterapkan pada dompet elektronik pada kasus. Hal ini dapat dilihat dari penilaian dari Bank Indonesia terhadap dompet elektronik tersebut. Selain masuk ke dalam kategori layanan dompet elektronik namun juga termasuk kedalam layanan uang elektronik. Pada BukaDompet dan TokoCash juga terdapat uang elekronik dimana floating fund telah mencapai Rp 1 Miliar maka dompet elektronik tersebut harus memiliki izin dari Bank Indonesia.

Tahapan selanjutnya adalah tahap perizinan. Perizinan disesuaikan dengan kategori dari penyelenggaraan jasa sistem pembayaran yang ditetapkan Bank Indonesia. Penyelenggara teknologi finansial kategori penyelenggara jasa sistem pembayaran harus memperoleh izin dari Bank Indonesia. BukaDompet dan TokoCash telah memiliki izin sebagai penyelenggara jasa sistem pembayaran. Namun, dengan diterbitkannya PBI Nomor 20/6/PBI/2018 tentang 
Uang Elektronik yang memberi kewajiban kepada dompet elektronik yang memiliki angka dana float diatas Rp 1.000.000.000 (satu milyar rupiah) maka wajib memiliki izin penerbit uang elektronik, sehingga Bank Indonesia mengambil langkah dengan melakukan pembekuan layanan operasional akibat belum adanya izin uang elektronik pada BukaDompet dan TokoCash. Analisa terhadap kasus bahwa jawaban atas perizinan dari Bank Indonesia memakan waktu yang lama dikarenakan baik BukaDompet dan TokoCash telah melakukan permohonan izin uang elektronik dari tahun 2017 dan hingga saat ini belum mendapat jawaban dari Bank Indonesia.

Dalam hal mengatasi perizinan tersebut, Bank Indonesia memberikan jalan keluar dengan memberikan pesetujuan pada kerja sama antara dompet elektronik. BukaDompet dan TokoCash melakukan kerja sama dengan dompet elektronik lain yang telah mendapatkan izin uang elektronik dari Bank Indonesia. Kerja sama penyelenggara jasa sistem pembayaran dengan penyelenggara teknologi finansial yang terdaftar harus terlebih dahulu memperoleh persetujuan Bank Indonesia. (Pasal 10, 15, dan 18 PBI tentang Teknologi Finansial) Bank Indonesia telah memberikan persetujuan pada kerja sama tersebut. Persyaratan yang dipenuhi dalam rangka bekerjasama dengan pihak lain yaitu aspek hukum, kinerja, serta legalitas dan profil perusahaan.

Tahap yang keempat yaitu pengawasan oleh Bank Indonesia. Analisa peran Bank Indonesia dalam kasus tersebut bahwa pihak Bank Indonesia lebih memilih untuk mengoptimalkan platform penyelenggara dompet elektronik yang sudah mengantongi izin dari Bank Indonesia dan telah melewati keempat tahapan sebagaimana dimaksud dalam Pasal 4 PBI Penyelenggaraan Teknologi Finansial. Bank Indonesia memberikan jalan keluar kepada dua dompet elektronik yang dibekukan operasionalnya untuk bekerja sama dengan pihak penyelenggara jasa sistem pembayaran yang lain yang sudah terotorisasi sebagai platform sistem pembayaran, dalam hal ini Tokopedia pada akhirnya bekerjasama dengan OVO sementara Bukalapak bekerjasama dengan dompet elektronik DANA. Persetujuan diberikan oleh Bank Indonesia dengan terpenuhinya persyaratan yang telah ditentukan Bank Indonesia pada PBI tentang Uang Elektronik. Persetujuan diberikan Bank Indonesia dikarenakan menjaga kelancaran dari sistem pembayaran merupakan tugas Bank Indonesia. Kelancaran sistem pembayaran dilakukan Bank Indonesia dengan tujuan memelihara stabilitas nilai rupiah. (Iskandar Simorangkir, 2014) BukaDompet dan TokoCash berhasil mendapat 
persetujuan Bank Indonesia untuk melakukan kerja sama, sehingga saldo dapat dipindahkan dari BukaDompet ke DANA dan begitu pula TokoCash ke OVO.

Tahapan pengawasan dan pemantauan terpenuhi pada implementasinya. Pengawasan dilakukan terhadap penyelenggara teknologi finansial berupa penyelenggara jasa sistem pembayaran sesuai dengan ketentuan Penyelenggara Transaksi Pembayaran. Pengawasan Bank Indonesia pada kasus sangat diterapkan dengan baik. Pengoptimalan ketentuan PBI tentang Uang Elektronik kepada dompet elektronik yang belum mendapatkan izin uang elektronik pada saat dana float diatas Rp 1 milyar. Pasal 16 dan 17 PBI tentang Penyelenggaraan Teknologi Finansial yang menyatakan pemantauan dilakukan terhadap penyelenggara teknologi finansial yang telah terdaftar penyelenggara teknologi finansial wajib menyampaikan data dan/atau informasi yang diminta oleh Bank Indonesia. Pasal 14 dan Pasal 12 PADG Nomor 19/15/PADG/2017 tentang Tata Cara Pendaftaran, Penyampaian Informasi, dan Pemantauan Penyelenggara Teknologi Finansial menyatakan bahwa penyelenggara teknologi finansial wajib menyampaikan informasi produk, layanan, teknologi dan/atau model bisnis. Data dan/atau informasi tersebut disampaikan secara bulanan yaitu pada minggu pertama bulan berikutnya.

Kasus pembekuan izin oleh Bank Indonesia terhadap beberapa dompet elektronik yang telah dipasarkan ke masyarakat telah menerapkan tahapan PBI penyelenggaraan teknologi finansial. Regulatory sandbox yang seharusnya merupakan tempat uji tuntas terbatas yang melingkupi keandalan dan efisien suatu layanan sistem pembayaran. Kemudian, adanya sertifikasi keandalan untuk memberikan standar mengenai keandalan sistem sehingga transaksi elektronik dapat lancar, aman, efisien, dan andal. Oleh karena itu, Bank Indonesia sebagai regulator telah mengatur dan mengawasi dengan baik mengenai penyelenggaraan dompet elektronik berdasarkan tatanan regulasi PBI Nomor 19/12/PBI/2017 tentang Penyelenggaraan Teknologi Finansial, PBI Nomor 20/6/PBI/2018 tentang Uang Elektronik, PBI Nomor 18/40/PBI/2016 tentang Penyelenggaraan Pemrosesan Transaksi Pembayaran guna mewujudkan sistem pembayaran dengan prinsip efisien, lancar, aman dan andal.

Kepastian Hukum Dalam Penyelenggaraan Dompet Elektronik Yang Dibekukan Layanan Operasional Oleh Bank Indonesia Berdasarkan PBI Nomor 20/6/PBI/2018 Tentang Uang Elektronik 
Dompet elektronik diatur dalam PBI Nomor 18/40/PBI/2016 tentang Penyelenggaraan Pemrosesan Transaksi Pembayaran yang memberikan hak dan kewajiban bagi pengguna dompet elektronik maupun penerbit dompet elektronik. Dompet elektronik juga merupakan kategori daripada teknologi finansial maka tunduk pada PBI Nomor 19/12/PBI/2017 tentang Penyelenggaraan Teknologi Finansial. Dompet elektronik dapat digunakan sebagai dompet yang menyimpan uang didalamnya, dompet elektronik menyimpan uang yang berbentuk alat pembayaran non tunai yaitu uang elektronik yang diatur dalam PBI Nomor 20/6/PBI/2018 tentang uang elektronik. Produk sistem pembayaran ini diibaratkan seperti sebuah "dompet" yang sering diletakkan dalam saku celana. Kegunaan dompet yang sering digunakan untuk menyimpan alat pembayaran seperti uang tunai maupun non tunai seperti kartu debit, kartu kredit. Namun yang membedakannya dengan dompet elektronik adalah dapat menyimpan uang elektronik, menyimpan data keuangan dari alat pembayaran non tunai yang dapat dipakai untuk melakukan pembayaran.

Pada dompet elektronik media penyimpanan nilai uang elektronik berdasarkan server based yaitu uang elektronik dengan media penyimpanan berupa server. Dalam penggunaanya diperlukan sebuah koneksi terlebih dahulu dengan penerbit dompet elektronik tersebut. Identitas pengguna dicatat berdasarkan jenisnya yaitu unregistered dan registered. Uang elektronik yang identitas penggunanya tidak terdaftar dan tidak tercatat pada penerbit disebut unregistered. Sedangkan, uang elektronik yang data identitas penggunanya terdaftar dan tercatat pada penerbit maka disebut sebagai registered. (Pasal 3 Ayat (2) PBI Nomor 20 Tahun 2018 tentang Uang Elektronik)

Nilai uang (monetary value) pada uang elektronik tersebut berbentuk elektronik (nilai elektronis) yang didapatkan dengan cara menukarkan sejumlah uang tunai atau debit rekeningnya di bank untuk kemudian disimpan secara elektronik dalam media elektronik berupa penyimpanan dana. Pengguna uang elektronik melakukan transaksi pembayaran atau transfer dana, maka nilai uang yang terdapat dalam uang elektronik tersebut juga akan berkurang sesuai dengan nilai transaksi pembayaran atau transfer dana yang dilakukan layaknya seperti uang tunai. Sebaliknya nilai uang pada uang elektronik akan bertambah bila menerima pembayaran atau penambahan dana yang dapat dilakukan dengan beragam cara baik melalui Anjungan Tunai Mandiri (ATM), merchant, virtual account, SMS Banking. Uang elektronik yang ada pada dompet elektronik telah diatur dalam PBI tentang uang elektronik.

PBI tentang Uang Elektronik maupun PBI Penyelenggaraan Transaksi Pembayaran menjelaskan bahwa penyelenggara jasa sistem pembayaran dapat melakukan kerja sama dengan penyelenggara jasa sistem pembayaran lainnya. Analisa kasus bahwa pada saat penerbit dibekukan operasional penyelenggaraan dompet elektroniknya, Bukalapak mulai memperkenalkan BukaDana di bulan September 2018 sebagai platform alternatif untuk pembayaran digital, Bukalapak akhirnya menutup BukaDompet yang telah beroperasi sejak tahun 2017 sebagai platform pembayaran utama dan mengalihkannya ke platform DANA. DANA memiliki izin sebagai penerbit uang elektronik sehingga memenuhi ketentuan dalam 
PBI tentang Uang Elektronik. TokoCash juga melakukan hal yang sama dengan BukaDompet yaitu melakukan migrasi dana ke OVO. Pengguna Tokocash secara otomatis akan mendapatkan saldo yang mereka punya seluruhnya pada akun OVO mereka masing-masing. Namun, pengguna harus melakukan aktivasi terlebih dahulu dengan menggunakan nomor telepon terdaftar yang sama dengan yang didaftarkan di TokoCash.

Pasca diberlakukannya PBI tentang Uang Elektronik tahun 2018 maka juga berlaku kebijakan bahwa setiap pihak yang bertindak sebagai penyelenggara wajib terlebih dahulu memperoleh izin dari Bank Indonesia. Untuk mendapatkan izin dari Bank Indonesia wajib memenuhi persyaratan umum dan aspek kelayakan. BukaDompet dibekukan operasionalnya oleh Bank Indonesia karena tidak memiliki izin uang elektronik untuk pengelolaan dompet digital dengan nominal diatas Rp. 1 Miliar, hal ini sama halnya dengan yang dialami oleh TokoCash milik Tokopedia. Dalam kasus ini Bank Indonesia melakukan hal tersebut sesuai dengan kewenangannya yang secara tegas diatur dalam Pasal 73 PBI Nomor 20/06/PBI/2018 tentang Uang Elektronik yang mengamanatkan bahwa apabila dalam hal hasil pengawasan Bank Indonesia menemukan penyelenggara yang tidak dapat menyelenggarakan kegiatan uang elektronik secara memadai, maka dalam kasus pembekuan operasional tersebut Bank Indonesia menghentikan sementara sebagian atau seluruh kegiatan penyelenggaraan uang elektronik. Namun pembekuan layanan operasional pada dompet elektronik tersebut diberikan jalan keluar oleh Bank Indonesia dengan memberikan persetujuan kerja sama dan dompet elektronik dapat memindahkan saldo pengguna ke dompet elektronik yang telah memiliki izin uang elektronik.

Kerja sama antar dompet elektronik tersebut juga harus mewujudkan kepastian hukum bagi pengguna dompet elektronik dengan menerapkan beberapa kewajiban sebagaimana tertuang dalam Pasal 34 PBI tentang Uang Elektronik yaitu menerapkan manajemen risiko secara efektif dan konsisten, menerapkan standar keamanan sistem informasi, memenuhi kewajiban pemrosesan transaksi uang elektronik secara domestik; dan melakukan interkoneksi dan interoperabilitas. Khusus untuk penyelenggara berupa penerbit maka wajib menerapkan prinsip anti pencucian uang dan pencegahan pendanaan terorisme dan menerapkan prinsip perlindungan konsumen. Selain beberapa kewajiban diatas, penyelenggara uang elektronik tersebut wajib pula menerapkan manajemen risiko secara efektif dan konsisten sebagaimana dimaksud dalam Pasal 35 PBI tentang Uang Elektronik seperti pengawasan aktif manajemen, kecukupan kebijakan dan prosedur serta struktur organisasi, kecukupan fungsi manajemen risiko dan sumber daya manusia dan pengendalian intern.

Dalam kasus ini terdapat penyelesaian yang berbeda antara BukaDompet dan TokoCash. BukaDompet melakukan penyelesaian permasalahan ketika izin beroperasionalnya dibekukan oleh Bank Indonesia yaitu dengan mengintegrasikan dompet elektronik BukaDompet ke dompet elektronik yang lain yaitu DANA yang telah memiliki izin beroperasi sebagai penyelenggara sistem pembayaran dari Bank Indonesia. Sementara itu hasil transaksi penjualan di BukaDompet tetap diakses oleh penjual di Bukalapak sebagai saldo dan dapat 
dicairkan, namun market place dan virtual product buyer akan diarahkan untuk menggunakan metode pembayaran lainnya. Pengguna BukaDompet yang masih memiliki saldo didalam akun BukaDompetnya dapat melakukan pencairan dana ke rekening bank dengan minimal transaksi Rp. 25.000 (dua puluh lima ribu rupiah) atau dapat dipindahkan ke dompet elektronik DANA dengan minimal saldo Rp. 10.000 (sepuluh ribu rupiah). Hal ini sesuai dengan ketentuan Pasal 61 PBI tentang Uang Elektronik. Sementara itu, TokoCash yang semula digunakan oleh Tokopedia, bekerjasama dengan pihak ketiga lainnya dalam hal ini adalah OVO untuk menjadi mitra yang menyelenggarakan sistem pembayaran di Tokopedia.

Kedua kasus diatas pada dasarnya diakibatkan permasalahan yang terjadi karena tidak memiliki lisensi untuk uang elektronik. Dengan demikian dompet elektronik yang memiliki visi sistem pembayaran pada tahun 2025 yang sejalan dengan uraian pada Blueprint sistem pembayaran bahwa digitalisasi pada dompet elektronik perlu bergerak sejalan dengan upaya menjaga stabilitas moneter dan stabilitas keuangan serta kelancaran sistem pembayaran. (Bank Indonesia, 2019) Pada satu sisi, interlink antara bank dengan teknologi finansial perlu dibangun dalam sebuah standar dan mekanisme kontraktual yang jelas. Regulasi yang dibentuk, entry-policy, pelaporan dan pengawasan perlu diselaraskan dengan tuntutan era digital termasuk aspek pengendalian risikonya.

Dengan demikian, keseluruhan penyelenggaraan transaksi sistem pembayaran dompet elektronik yang dilakukan oleh TokoCash maupun BukaDompet, diperoleh hasil bahwa pembekuan layanan operasional dompet elektronik oleh Bank Indonesia telah memenuhi asas kepastian hukum. Hal ini dapat dilihat dari penyelesaian kasus pemebekuan izin operasional usaha TokoCash maupun BukaDompet dapat diatasi dengan baik dengan menerapkan beberapa kaidah hukum yang tercantum dalam PBI tentang Uang Elektronik. Pemenuhan aspek kepastian hukum tersebut dilakukan dengan melakukan kerja sama antara dompet elektronik yang dibekukan layanan operasional dengan dompet elektronik yang memiliki izin uang elektronik dari Bank Indonesia. Kerja sama tersebut dilakukan sesuai dengan ketentuan PBI tentang Uang Elektronik dan PBI Penyelenggaraan Pemrosesan Transaksi Pembayaran. Setelah dilakukannya kerja sama maka saldo pengguna dari dompet elektronik yang dibekukan dilakukan pemindahan ke dompet elektronik yang telah mendapatkan izin uang elektronik dari Bank Indonesia. Namun, tetap memenuhi persyaratan untuk mendapatkan persetujuan kerja sama oleh Bank Indonesia dalam PBI tentang Uang Elektronik dan PBI Penyelenggaraan Transaksi Pembayaran.

Aspek manajemen risiko secara efektif dan konsisten harus diterapkan dalam penyelenggaraan pemrosesan transaksi pembayaran sesuai dengan PBI 18/40/PBI/2016 tentang Penyelenggaraan Pemrosesan Transaksi Pembayaran diatur dalam Pasal 19 yang mencakup pengawasan aktif manajemen, kecukupan kebijakan dan prosedur, fungsi manajemen risiko dan sumber daya manusia pelaksana. Sehingga jika terjadi permasalahan seperti kasus, dapat menyelesaikan dengan pernyataan aspek manajemen risiko pada PBI tentang uang elektronik yang menjadi kewajiban penerbit yaitu kebijakan dan prosedur penerapan manajemen risiko, kebijakan dan prosedur penerapan perlindungan konsumen. 
Konsep penerapan manajemen risiko berupa bukti kesiapan penerapan manajemen risiko yang paling sedikit berupa risiko operasional, risiko hukum, risiko setelmen, risiko likuiditas, risiko market conduct dan risiko reputasi.

Penerapan manajemen risiko dibuktikan dengan hasil penilaian terhadap manajemen risiko yang telah diselenggarakan serta rencana penyesuaian kebijakan dan prosedur manajemen risiko atas pengembangan produk yang diselenggarakan. Manajemen risiko tersebut akan diawasi secara aktif berupa penetapan akuntabilitas, kebijakan dan proses pengendalian untuk mengelola risiko yang mungkin timbul dari penyelenggara dompet elektronik. Penerapan manajemen risiko tersebut untuk risiko keuangan bagi Penerbit yaitu pembatasan nilai uang elektronik, dan pengelolan dana float. (Penjelasan Pasal 37 PBI tentang Uang Elektronik)

Bentuk kepastian hukum bagi pengguna dompet elektronik saat terjadi permasalahan pada penyelenggaraan dompet elektronik juga diatur dalam PBI Nomor 16/1/PBI/2014 tentang Perlindungan Konsumen Jasa Sistem Pembayaran hal ini guna menjamin adanya kepastian hukum untuk memberi perlindungan kepada konsumen jasa sistem pembayaran yang pada penelitian ini ditujukan bagi pengguna dompet elektronik. Prinsip pengendalian konsumen yang terdiri dari keadilan dan keandalan, transparansi, perlindungan data dan/atau informasi konsumen, serta penanganan dan penyelesaian pengaduan yang efektif. (PBI tentang Perlindungan Konsumen Jasa Sistem Pembayaran) Oleh karena itu, PBI perlindungan konsumen, PBI Penyelenggaraan Pemrosesan Transaksi Pembayaran, PBI tentang Uang Elektronik, dan PBI Teknologi Finansial telah diterapkan, sehingga pada kasus pembekuan layanan operasional penyelenggaraan dompet elektronik oleh Bank Indonesia telah memenuhi kepastian hukum.

\section{KESIMPULAN}

Prinsip lancar, aman, efisien, dan andal terhadap usaha dompet elektronik dalam mekanisme teknologi finansial yang ditijau dari PBI Nomor 20/6/PBI/2018 tentang Uang Elektronik telah diatur dengan baik oleh Bank Indonesia sebagai regulator dalam sistem pembayaran. Bank Indonesia telah menjalankan sistem pengawasan sesuai dengan norma hukum atas kasus tersebut TokoCash dan BukaDompet yang beroperasi sebelum diberlakukan perubahan PBI tentang Uang Elektronik kemudian ketika PBI tersebut diberlakukan maka dompet elektronik tersebut dibekukan operasionalnya. Hal ini merupakan bentuk sistem pengawasan Bank Indonesia yang konkrit dalam rangka menwujudkan prinsip lancar, aman, efisien, dan andal. Namun berkaitan dengan pemberian izin, Bank Indonesia dapat mengatur secara konkrit jangka waktu yang jelas terkait penerbitan izin uang elektronik. Sehingga, dompet elektronik dapat melakukan penyelesaian masalah kegiatan operasional dengan efektif. 
Penyelenggara dompet elektronik yang dibekukan layanan operasionalnya oleh Bank Indonesia telah memenuhi aspek kepastian hukum dengan menerapkan ketentuan PBI tentang Uang Elektronik dan juga PBI Penyelenggaraan Pemrosesan Transaksi Pembayaran yaitu melakukan kerja sama dengan dompet elektronik lain yang telah memiliki izin uang elektronik dari Bank Indonesia kemudian saldo pengguna seluruhnya dipindahkan ke dompet elektronik yang telah diadakan kerja sama. Bank Indonesia dapat mengatur secara jelas dalam Surat Edaran Bank Indonesia mengenai penyelenggara dompet elektronik. Aturan berupa pemberian tanda otorisasi pada tampilan dompet elektronik sehingga pengguna dapat mengetahui dompet elektronik yang telah mendapatkan izin dari Bank Indonesia. Dengan demikian sistem pembayaran dapat dilakukan sesuai dengan tujuan penyelenggaraan dompet elektronik yang mewujudkan visi sistem pembayaran.

\section{KEPUSTAKAAN}

Abubakar, L dan Handayani, T. (2018). Financial Technology: Legal Challenges for Indonesia Financial Sector. IOP Conf. Series Earth and Environmental Science. 175012204.

Abubakar, L dan Handayani, T. (2018). Perkembangan Transaksi di Sektor Jasa Keuangan dan Kontribusinya Terhadap Pembaharuan Hukum Kontrak Nasional. Buletin Hukum Kebanksentralan. 15(1).

Bank Indonesia. (2018). Peraturan Bank Indonesia Nomor 20/6/PBI/2018 Tentang Uang Elektronik. Jakarta: Author.

Bank Indonesia. (2016). Peraturan Bank Indonesia Nomor 18/40/PBI/2016 Tentang Penyelenggaraan Pemrosesan Transaksi Pembayaran. Jakarta: Author.

Bank Indonesia. (2017). Peraturan Bank Indonesia Nomor 19/12/PBI/2017 Tentang Penyelenggaraan Teknologi Finansial. Jakarta: Author

Bank Indonesia. (2019). Bank Indonesia: Menavigasi Sistem Pembayaran Nasional di Era Digital. Blueprint Sistem Pembayaran Indonesia 2025.

Bohang, F, K. (2018, Oktober 01). Dompet Digital Tunggu Kabar Dari Bank Indonesia. Kompas. Retrieved from https://tekno.kompas.com/read/2018/01/10/19310047/dompetdigital-dibekukan-bukalapak-tunggu-kabar-dari-bi

Bohang, F, K. (2017, Desember 13). Sejauh Mana Proses Perizinan Dompet Digital Tokopedia? Kompas. Retrieved from https://tekno.kompas.com/read/2017/12/13/13080467/3bulan-dibekukan-sejauh-mana-proses-perizinan-dompet-digital-tokopedia

Farida, M. (2007). Ilmu Perundang-undangan Proses dan Teknik Pembentukannya. Yogyakarta, Indonesia: Kanisius.

Simorangkir, I. (2014). Pengantar Kebanksentralan: Teori dan Praktik di Indonesia. Jakarta, Indonesia: Rajawali Press.

Mintarsih. (2013). Perlindungan Konsumen Pemegang Uang Elektronik (E-Money) Dihubungkan Dengan Undang-Undang Nomor 8 Tahun 1999 Tentang Perlindungan Konsumen. Jurnal Wawasan Hukum. 29. 
R, P, Buckley dan Webster. (2016). Fintech in Developing Countries: Charting New Costumer Journeys. Journal of Financial Transformation. 44.

S, G, Dewan dan L, D, Chen. (2014). Mobile Payment Adoption in the USA: a Cross Industry, Cross-platform Solution, Journal Information Privacy and Security. 1.

Tribun. (2017, November 10). Sebulan Lebih TokoCash Tokopedia Dibekukan BI, Ini Dampak yang Dirasakan. Tribun. Retrieved from https://batam.tribunnews.com/2017/11/10/sebulan-lebih-tokocash-tokopedia-dibekukan-biini-dampak-yang-dirasakan 